\title{
ANALISIS FAKTOR MANAJEMEN PROYEK DOMINAN YANG MEMPENGARUHI PELAKSANAAN PROYEK INFRASTRUKTUR DI DAERAH PEDESAAAN
}

\author{
Hansen $^{1}$ dan Basuki Anondho ${ }^{2}$ \\ ${ }^{1}$ Program Studi Sarjana Teknik Sipil, Universitas Tarumanagara, Jl. Letjen S. Parman No.1 Jakarta \\ Email: hanseen@gmail.com \\ ${ }^{2}$ Senior Lecturer Teknik Sipil, Universitas Tarumanagara, Jl. Letjen S. Parman No.1 Jakarta \\ Email: basukia@ft.untar.ac.id
}

\begin{abstract}
ABSTRAK
Berdasarkan Indeks Desa Membangun (IDM) yang dikeluarkan Kementerian Desa Tahun 2015, terdapat $61 \%$ desa di 122 daerah (kabupaten) tertinggal tergolong sangat tertinggal dan $28 \%$ tergolong tertinggal. Munculnya daerah tertinggal disebabkan karena adanya kesenjangan pembangunan antara desa dan kota di Indonesia. Untuk mengurangi kesenjangan pembangunan diperlukan pembangunan daerah tertinggal. Salah satunya adalah melakukan pembangunan infrastruktur di daerah tertinggal yang telah ditetapkan oleh Kementerian Desa dalam Rencana Pembangunan Jangka Menengah Nasional (RPJMN) 2015-2019. Manajemen proyek konstruksi di desa dapat menjadi tantangan karena sumber daya yang sangat terbatas, faktor risiko yang unik, lokasi terpencil, dan kurangnya ahli manajemen konstruksi. Dalam pelaksanaannya akan muncul berbagai macam masalah yang dipengaruhi oleh faktor-faktor pengaruh. Karakteristik pedesaan yang berbeda-beda menyebabkan adanya kemungkinan faktor pengaruh terhadap pelaksanaan konstruksi dapat berbeda. Penelitian ini akan mengidentifikasi faktor-faktor manajemen proyek dominan yang mempengaruhi pelaksanaan proyek pembangunan infrastruktur di daerah pedesaan. Penelitian dilakukan dengan penyebaran kuesioner kepada manajer kontraktor dari Kementerian Desa yang pernah terlibat dalam proyek infrastruktur jalan, jembatan, dan embung di suatu daerah pedesaan. Analisis data dilakukan dengan metode analisis faktor yang perhitungannya menggunakan program SPSS. Hasil menunjukkan bahwa faktor-faktor manajemen proyek dominan yang mempengaruhi pelaksanaan proyek pembangunan infrastruktur di daerah pedesaan adalah komunikasi, teknologi, biaya, kondisi cuaca, material, dokumentasi, dan skala kontraktor.
\end{abstract}

Kata kunci: manajemen proyek, proyek konstruksi, infrastruktur, dan desa.

\section{PENDAHULUAN}

\section{Latar Belakang}

Berdasarkan Rencana Pembangunan Jangka Menengah Nasional (RPJMN) 2015-2019, percepatan pembangunan difokuskan pada 122 kabupaten yang dikategorikan daerah tertinggal. Berdasarkan Indeks Desa Membangun (IDM) yang dikeluarkan Kementerian Desa, Pembangunan Daerah Tertinggal dan Transmigrasi tahun 2015, terdapat 61\% desa di 122 daerah tertinggal tergolong sangat tertinggal dan 28\% tergolong tertinggal. Suatu daerah dikatakan sebagai daerah tertinggal karena kondisi geografis yang sulit dijangkau, tidak memiliki potensi sumber daya alam, keterbatasan sarana dan prasarana, daerah rawan bencana dan konflik, serta kebijakan pembangunan yang tidak tepat. Salah satu penyebab munculnya daerah tertinggal adalah adanya kesenjangan pembangunan yang terjadi di Indonesia, misalnya antara desa dan kota. Untuk mengurangi kesenjangan pembangunan diperlukan upaya pembangunan daerah tertinggal. Salah satu upaya yang dapat dilakukan adalah melakukan pembangunan sarana dan prasarana (infrastruktur) di daerah tertinggal (Badan Penelitian dan Pengembangan, Pendidikan dan Pelatihan, dan Informasi, Kementerian Desa, Pembangunan Daerah Tertinggal dan Transmigrasi, 2015).

Manajemen proyek konstruksi di daerah pedesaan dapat menjadi tantangan karena sumber daya yang sangat terbatas, faktor risiko yang unik, lokasi yang terpencil, dan kurangnya ahli manajemen konstruksi. Banyak perhatian telah diberikan untuk mengidentifikasi dan mendokumentasi praktik manajemen terbaik untuk proyek konstruksi di perkotaan. Sayangnya, banyak dari sumber daya ini tidak dapat dengan mudah diterapkan dalam konstruksi di pedesaan (Tran, et al, 2015). 
Dalam tahap pelaksanaan (construction) akan mulai muncul berbagai masalah yang mempengaruhi proses pembangunan, mulai dari masalah teknis dan non teknis, baik yang bersifat internal proyek maupun eksternal proyek. Masalah tersebut pada dasarnya muncul ketika proyek tidak mampu mencapai triangle project constraint dengan baik, yaitu mutu, biaya, dan waktu (Project Management Body of Knowledges Edisi keenam, 2017).

Di desa memiliki beberapa karakteristik yang berbeda, seperti geografis, sumber daya, demografis, dan lain sebagainya. Hal ini menyebabkan ada kemungkinan faktor pengaruh terhadap pelaksanaan konstruksi dapat berbeda. Pengetahuan tentang faktor-faktor spesifik di pedesaan yang mempengaruhi proses suatu proyek konstruksi akan sangat membantu manajemen proyek konstruksi di pedesaan. Hal ini menjadi dasar penelitian identifikasi faktorfaktor manajemen proyek yang mempengaruhi pelaksanaan proyek infrastruktur di daerah pedesaan.

\section{Rumusan Masalah}

Sebagai tahap awal, dibutuhkan identifikasi faktor-faktor manajemen proyek dominan yang mempengaruhi pelaksanaan proyek infrastruktur di daerah pedesaan.

\section{Ruang Lingkup Penelitian}

Untuk memfokuskan pada tujuan penelitian, maka dibatasi ruang lingkup penelitian sebagai berikut:

1. Pengumpulan data dengan alat ukur kuesioner yang disusun berdasarkan identifikasi awal.

2. Identifikasi faktor pengaruh dilakukan dengan analisis faktor dominan.

\section{Batasan Penelitian}

Dalam penelitian ini dilakukan pembatasan masalah agar pelaksanaan serta hasil yang akan diperoleh sesuai dengan tujuan penelitian. Adapun batasan penelitiannya adalah sebagai berikut:

1. Responden adalah kontraktor pada Kementerian Desa, Pembangunan Daerah Tertinggal dan Transmigrasi, yang terlibat dalam proyek infrastruktur di daerah pedesaan.

2. Identifikasi faktor dilakukan terhadap proyek-proyek teknik sipil di lingkungan Dirjen Kementerian Desa, Pembangunan Daerah Tertentu.

\section{Manfaat Penelitian}

Penelitian ini diharapkan dapat memberikan informasi kepada pihak perusahaan kontraktor di PDTu tentang faktorfaktor pengaruh pelaksanaan proyek pembangunan sebagai pengetahuan/ wawasan yang diharapkan dapat diterapkan dalam meningkatkan pembangunan infrastruktur di daerah pedesaan di Indonesia.

\section{TINJAUAN PUSTAKA}

Studi Literatur melalui buku tentang pembangunan daerah tertinggal, manajemen proyek, dan kontraktor, serta melalui jurnal-jurnal internasional tentang faktor pengaruh pelaksanaan proyek pembangunan di daerah pedesaan.

\section{Pembangunan Daerah Tertinggal}

Pembangunan daerah tertinggal menurut Peraturan Pemerintah nomor 78 tahun 2014 adalah upaya terencana untuk mengubah suatu daerah yang dihuni oleh komunitas dengan berbagai permasalahan sosial ekonomi dan keterbatasan fisik, menjadikan daerah yang maju dengan komunitas yang kualitas hidupnya sama atau tidak jauh tertinggal dibandingkan dengan masyarakat Indonesia lainnya.

Isu-isu strategis dalam Pembangunan di daerah tertinggal, antara lain (Badan Penelitian dan Pengembangan, Pendidikan dan Pelatihan, dan Informasi, Kementerian Desa, Pembangunan Daerah Tertinggal dan Transmigrasi, 2015):

1. Belum optimalnya pembangunan antar sektor yang mengakibatkan lemahnya koordinasi antara pelaku pembangunan.

2. Belum optimalnya kerangka sistem kelembagaan yang menempatkan masing-masing pelaku pada tugas dan fungsi yang jelas.

3. Terbatasnya sarana dan prasarana serta aksesibilitas daerah tertinggal terhadap wilayah yang cepat tumbuh.

4. Pemanfaatan sumber daya lokal belum optimal sebagai sumber daya perekonomian di daerah tertinggal.

5. Terbatasnya kemampuan keuangan daerah dan rendahnya kualitas belanja di daerah tertinggal. 
Dalam pelaksanaannya, jenis kegiatan yang dapat dipilih menjadi fasilitas kegiatan Ditjen PDTu pada Direktorat Pengembangan Daerah Perbatasan, meliputi (Direktorat Jenderal Pengembangan Daerah Tertentu, Kementerian Desa, Pembangunan Daerah Tertinggal dan Transmigrasi, 2015):

- Pengadaan PLTS 5 dan 10 Kwp;

- Pembangunan fasilitas air bersih;

- Pembangunan jembatan;

- Pembangunan jalan;

- Pembangunan embung;
- Pengembangan potensi sumber daya;

- Pembangunan media informasi televisi (MIT);

- Pengadaan alat peraga untuk pendidikan; dan

- Pembangunan pondok singgah.

\section{Manajemen Proyek}

Manajemen proyek adalah penerapan pengetahuan (knowledges), keterampilan (skills), alat (tools), dan teknik (techniques) dalam kegiatan-kegiatan proyek untuk memenuhi persyaratan proyek (Project Management Book of Knowledge Edisi keenam, 2017). Manajemen proyek memiliki karakteristik unik yang melibatkan banyak sumber daya dan membutuhkan organisasi. Dalam proses penyelesaiannya harus berpegang pada tiga kendala (triple constraint), yaitu: sesuai spesifikasi yang ditetapkan, sesuai time schedule, dan sesuai anggaran yang ditetapkan. Manajemen proyek bertujuan untuk mendapatkan metode atau cara teknis yang paling baik agar dengan sumber daya yang terbatas dapat diperoleh hasil maksimal dalam ketepatan, kecepatan, dan keselamatan kerja yang komprehensif (Anondho, 2018).

Kelompok proses pelaksanaan manajemen proyek terdiri dari proses-proses yang dilakukan untuk menyelesaikan pekerjaan yang terdefinisi dalam rencana untuk memenuhi persyaratan proyek. Dalam kelompok proses ini terdiri dari mengoordinasikan sumber daya, mengelola keterlibatan pemangku kepentingan, mengintegrasikan dan melakukan aktivitas proyek sesuai dengan rencana. Sebagian besar anggaran, sumber daya, dan waktu proyek digunakan untuk melakukan proses-proses pada kelompok proses pelaksanaan. (Project Management Book of Knowledge Edisi keenam, 2017).

\section{Kontraktor}

Kontraktor adalah orang atau badan yang menerima pekerjaan dan menyelenggarakan pekerjaan sesuai biaya yang telah ditetapkan berdasarkan gambar rencana, peraturan, dan syarat-syarat yang ditetapkan (Ervianto, 2005).

Berdasarkan data yang diperoleh dari Badan Pusat Statistik (BPS) tahun 2018, jumlah kontraktor di Indonesia yang terdaftar di Lembaga Pengembangan Jasa Konstruksi (LPJK) berjumlah 160.576 kontraktor, yang terdiri dari 130.771 (83,65\%) kontraktor golongan kecil, 28.254 (15,48\%) kontraktor golongan menengah, dan $1.551(0,86 \%)$ kontraktor golongan besar.

\section{Identifikasi Awal Faktor Pengaruh}

Identifikasi awal dilakukan dengan mencari faktor pengaruh dari buku dan jurnal, kemudian mengelompokkan faktor pengaruh yang sejenis dan menetapkan variabel dari faktor tersebut.

Tabel 1. Identifikasi Awal Faktor Pengaruh

\begin{tabular}{|c|c|c|c|}
\hline No & Jurnal, Pengarang, Tahun & Faktor Pengaruh & Variabel \\
\hline \multirow[t]{6}{*}{1} & \multirow{6}{*}{ 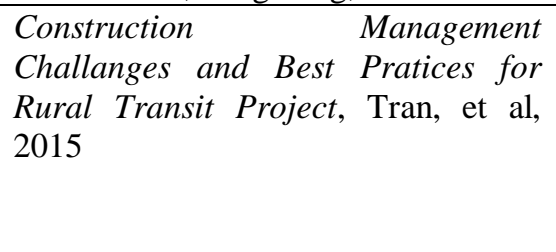 } & Dokumentasi & Dokumentasi \\
\hline & & Kepegawaian & Tenaga kerja \\
\hline & & Lokasi Terpencil & Lokasi \\
\hline & & Kontraktor kecil & Skala kontraktor \\
\hline & & Komunikasi & Komunikasi \\
\hline & & Isu lokal dan lingkungan & Lingkungan \\
\hline \multirow[t]{2}{*}{2} & \multirow{2}{*}{$\begin{array}{l}\text { Role of The Engineer in Rural } \\
\text { Municipalities, Randolph, et al, } 2003\end{array}$} & Tanggung jawab administratif & Dokumentasi \\
\hline & & Tanggung jawab hubungan publik & Komunikasi \\
\hline \multirow[t]{6}{*}{3} & \multirow{6}{*}{$\begin{array}{l}\text { Development of The Cost Baseline } \\
\text { for Achieving Excellence in Rural } \\
\text { Transit Facilities, Kermanshachi, et } \\
\text { al, } 2018\end{array}$} & Kondisi tanah & Kondisi situs \\
\hline & & Isu lingkungan & Lingkungan \\
\hline & & Kondisi cuaca tidak terduga & Cuaca \\
\hline & & Keluhan dari lingkungan & Lingkungan \\
\hline & & Kurangnya dana & Biaya \\
\hline & & Bahan & Material \\
\hline \multirow[t]{3}{*}{4} & \multirow{3}{*}{$\begin{array}{l}\text { Studi of Factors Influencing } \\
\text { Construction Delays at } \\
\text { Malaysial } \text {, Ramli, et al, } 2018\end{array}$} & Akses ke situs konstruksi & Lokasi \\
\hline & & Kondisi situs & Kondisi situs \\
\hline & & Fluktuasi material & Material \\
\hline
\end{tabular}


Tabel 1. Identifikasi Awal Faktor Pengaruh (Lanjutan)

\begin{tabular}{|c|c|c|c|}
\hline & & Pengiriman bahan & Material \\
\hline & & Ketersediaan tenaga kerja & Tenaga kerja \\
\hline & & Produktivitas tenaga kerja & Tenaga kerja \\
\hline & & Jumlah terampil buruh & Tenaga kerja \\
\hline & & Kualifikasi kontraktor & Skala kontraktor \\
\hline & & $\begin{array}{c}\text { Kinerja kontraktor (komunikasi } \\
\text { dan teknologi) }\end{array}$ & Teknologi \\
\hline & & Manajemen situs & Lingkungan \\
\hline & & Pengambilan keputusan & Keputusan \\
\hline & & Kondisi cuaca & Cuaca \\
\hline \multirow[t]{3}{*}{5} & \multirow{3}{*}{$\begin{array}{l}\text { The Analysis and Recommended } \\
\text { Solutions for Rural Roads in China, } \\
\text { Lin, et al, } 2010\end{array}$} & Kekurangan dana & Biaya \\
\hline & & Keterbatasan dukungan teknologi & Teknologi \\
\hline & & Lingkungan setempat & Kondisi situs \\
\hline \multirow[t]{10}{*}{6} & \multirow{10}{*}{$\begin{array}{l}\text { Project Management Book of } \\
\text { Knowledge Edisi Keenam, Project } \\
\text { Management Institute, } 2017\end{array}$} & Pengelolaan pekerjaan proyek & Pekerjaan \\
\hline & & Pengelolaan pekerjaan proyek & Pekerjaan \\
\hline & & Pengelolaan mutu & Bahan, Tenaga kerja \\
\hline & & Pemerolehan sumber daya & Bahan, Tenaga kerja \\
\hline & & Dokumen proyek & Dokumentasi \\
\hline & & Pengelolaan komunikasi & Komunikasi \\
\hline & & Pelaksanaan pengadaan & Komunikasi \\
\hline & & $\begin{array}{l}\text { Keterlibatan pemangku } \\
\text { kepentingan }\end{array}$ & $\begin{array}{l}\text { Pemangku } \\
\text { kepentingan }\end{array}$ \\
\hline & & Pengendalian jadwal & Jadwal \\
\hline & & Pengendalian biaya & Biaya \\
\hline \multirow[t]{8}{*}{7} & \multirow{8}{*}{$\begin{array}{l}\text { Rencana Strategis Pembangunan } \\
\text { Daerah Tertentu 2015 - 2019, } \\
\text { Direktorat Jenderal Pembangunan } \\
\text { Daerah Tertentu, Kementerian Desa, } \\
\text { Pembangunan Daerah Tertentu dan } \\
\text { Transmigrasi, 2015 }\end{array}$} & Potensi sumber daya lokal & Bahan \\
\hline & & Jenis permukaan jalan desa & Kondisi situs \\
\hline & & Akses ke daerah tertinggal & Lokasi \\
\hline & & Sarana komunikasi & Komunikasi \\
\hline & & Lokasi terpencil & Lokasi \\
\hline & & Jumlah dan kualitas SDM & Tenaga kerja \\
\hline & & Terbatasnya dukungan IT & Teknologi \\
\hline & & $\begin{array}{c}\text { Peningkatan kerja sama dalam } \\
\text { bidang pembangunan }\end{array}$ & Komunikasi \\
\hline
\end{tabular}

Selanjutnya melakukan tabulasi terhadap variabel yang diperoleh.

Tabel 2. Hasil Tabulasi Variabel

\begin{tabular}{|c|c|c|c|c|c|c|c|c|}
\hline \multirow{2}{*}{ No } & \multirow{2}{*}{ Variabel } & \multicolumn{5}{|c|}{ Jurnal } & \multicolumn{2}{|c|}{ Buku } \\
\hline & & 1 & 2 & 3 & 4 & 5 & PMBOK & PDTu \\
\hline 1 & Dokumentasi & $x$ & $x$ & & & & $x$ & \\
\hline 2 & Tenaga Kerja & $x$ & & & $x$ & & $x$ & $x$ \\
\hline 3 & Lokasi & $x$ & & & $x$ & $x$ & & $x$ \\
\hline 4 & Skala Kontraktor & $x$ & & & $x$ & & & \\
\hline 5 & Komunikasi & $x$ & $x$ & & & & $x$ & $x$ \\
\hline 6 & Lingkungan & $x$ & & $x$ & & & & \\
\hline 7 & Kondisi Situs & & & $x$ & $x$ & & & $x$ \\
\hline 8 & Kondisi Cuaca & & & $x$ & $x$ & & & \\
\hline 9 & Biaya & & & $x$ & & $x$ & $x$ & \\
\hline 10 & Material & & & $x$ & $x$ & & $x$ & $x$ \\
\hline 11 & Teknologi & & & & $x$ & $x$ & & $x$ \\
\hline 12 & Keputusan & & & & $x$ & & & \\
\hline 13 & Pekerjaan & & & & & & $x$ & \\
\hline 14 & Jadwal & & & & & & $x$ & \\
\hline 15 & Pemangku Kepentingan & & & & & & $x$ & \\
\hline
\end{tabular}


Variabel yang minimal terdapat di dua literatur akan digunakan dalam penyusunan kuesioner. Variabel-variabel tersebut, antara lain:

1. Dokumentasi

Tran, et al, (2015) menyatakan bahwa dokumentasi dibutuhkan dalam administrasi pembangunan. Pencatatan merupakan bagian dari administrasi kontrak yang dibutuhkan dalam proyek di pedesaan.

\section{Tenaga Kerja}

Ramli, et al, (2018) menyatakan bahwa sebagian besar proyek di daerah pedesaan memiliki masalah untuk merekrut dan mempertahankan staf. Kurangnya tenaga kerja yang terampil dan berpengalaman menjadi salah satu faktor yang menyebabkan keterlambatan proyek konstruksi.

\section{Lokasi}

Ramli, et al, (2018) berpendapat bahwa akses terbatas ke lokasi proyek merupakan salah satu faktor yang menyebabkan penundaan dalam proyek pembangunan desa. Banyak yang perlu dipertimbangkan tentang akses ke situs di mana proyek biasanya di daerah pedesaan jauh dari kantor pusat sehingga perlu mengelola waktu perjalanan.

\section{Skala Kontraktor}

Tran, et al, (2015) menyatakan kontraktor kecil memiliki dampak pada teknik penjadwalan pada proyek di pedesaan. Teknik penjadwalan yang tepat adalah kunci keberhasilan untuk proyek-proyek di pedesaan. Hasil penelitian menunjukkan bahwa sebagian besar kontraktor tidak menggunakan software penjadwalan untuk proyek di pedesaan.

\section{Komunikasi}

Tran, et al, (2015) menyatakan bahwa komunikasi memainkan peran penting dalam keberhasilan proyek pembangunan desa. Proyek pedesaan biasanya terletak cukup jauh dari kantor kontraktor. Isu-isu seperti waktu perjalanan, tidak memiliki jaringan internet berkecepatan tinggi, dan layanan seluler merupakan tantangan utama dari komunikasi untuk proyek-proyek pembangunan di daerah pedesaan.

\section{Lingkungan}

Menurut Tran, et al, (2015), isu lingkungan mempengaruhi operasi pelaksanaan proyek pembangunan pedesaan. Terdapat banyak karakteristik dari proyek pedesaan yang mungkin memiliki dampak signifikan pada penjadwalan proyek. Tujuan sekunder dari sebagian besar proyek pedesaan adalah untuk meningkatkan kerja sama komunitas kecil dan melindungi lingkungan alam pedesaan.

\section{Kondisi Situs}

Menurut Ramli, et al, (2018), kondisi situs dapat mempengaruhi waktu penyelesaian proyek konstruksi yang melibatkan kondisi bawah tanah dan kegiatan yang dimulai pada awal proyek konstruksi. Sebuah penyelidikan terperinci dan persiapan sebelum dimulainya proyek konstruksi dibutuhkan untuk menghindari kondisi tanah yang tidak terduga di mana biasanya kondisi tanah alami tidak bisa diprediksi.

\section{Kondisi Cuaca}

Kermanshachi, et al, (2018) menyatakan kondisi cuaca dapat mempengaruhi motivasi tenaga kerja yang menyebabkan keterlambatan pada proyek pembangunan desa.

\section{Biaya}

Lin, et al, (2010) menyatakan bahwa pembangunan jalan juga menghadapi masalah kekurangan dana. Untuk menghadapi kekurangan dana, insinyur harus menggunakan teknologi yang mungkin untuk mengurangi biaya konstruksi jalan seperti menciptakan bahan bangunan baru dan peralatan baru.

\section{Material}

Kermanshaci, et al, (2018) menyatakan bahan merupakan salah satu faktor risiko proyek pembangunan desa. Ketidaktetapan biaya bahan untuk pembangunan jalan dapat menyebabkan pembengkakan biaya.

\section{Teknologi}

Ramli, et al, (2018) menyatakan bahwa keterbatasan kemampuan untuk komunikasi dan biasanya kontraktor tidak menggunakan perangkat lunak (software) penjadwalan, menyebabkan risiko proyek tertunda. 


\section{METODOLOGI PENELITIAN}

Penelitian ini menggunakan tipe penelitian kuantitatif yang artinya menggunakan data berupa angka sebagai alat untuk menganalisis keterangan mengenai apa yang ingin diketahui. Penelitian kuantitatif didasarkan pada asumsi variabel dapat diidentifikasi dan diukur dengan alat-alat yang objektif dan baku. Metode yang digunakan dalam penelitian kuantitatif adalah metode survei ekspanatori (explanatory survey), yaitu penelitian yang mengambil sampel dari suatu populasi dan menggunakan instrumen penelitian berupa kuesioner sebagai alat pengumpulan data. Kuesioner penelitian ini dipergunakan untuk mengukur sikap, pendapat, dan persepsi seseorang atau sekelompok orang (kontraktor) tentang suatu gejala, yaitu faktor-faktor pengaruh dalam pelaksanaan proyek pembangunan infrastruktur di daerah pedesaan, maka dari itu kuesioner akan dibuat menggunakan skala Likert (Hidayat, 2012).

\section{Penyusunan Kuesioner}

Penyusunan kuesioner terdiri dari sampul (cover), kata pengantar, catatan, data diri responden, data proyek, dan isi kuesioner mengenai faktor manajemen proyek. Isi kuesioner terdiri dari kalimat pengantar dan daftar pernyataan yang akan diisi oleh responden. Kalimat pernyataan dibuat berdasarkan pembahasan variabel yang terdapat di jurnal. Jumlah pernyataan dibatasi satu pernyataan untuk satu variabel untuk menghindari perubahan variabel dalam analisis faktor menggunakan program SPSS.

Tabel 3. Pernyataan Kuesioner

\begin{tabular}{|c|c|c|}
\hline No & Variabel & Pernyataan \\
\hline 1 & Dokumentasi & $\begin{array}{l}\text { Adanya laporan rutin progress pekerjaan yang disetujui oleh } \\
\text { pemangku kepentingan mempengaruhi keberlangsungan suatu } \\
\text { proyek konstruksi di desa. }\end{array}$ \\
\hline 2 & Lokasi & $\begin{array}{l}\text { Letak lokasi desa secara geografis berdampak kepada proses } \\
\text { pengadaan sumber daya. }\end{array}$ \\
\hline 3 & Skala kontraktor & $\begin{array}{l}\text { Kemampuan pelaksanaan proyek konstruksi di pedesaan } \\
\text { tergantung pada skala kontraktor. }\end{array}$ \\
\hline 4 & Komunikasi & $\begin{array}{l}\text { Adanya perjanjian tertulis antar pihak berkepentingan terkait akan } \\
\text { melancarkan pelaksanaan proyek konstruksi di pedesaan. }\end{array}$ \\
\hline 5 & Lingkungan & $\begin{array}{l}\text { Lingkungan setempat mempengaruhi operasi pelaksanaan pada } \\
\text { daerah pedesaan. }\end{array}$ \\
\hline 6 & Kondisi : & $\begin{array}{l}\text { Survei kondisi tanah yang dilakukan sebelum memulai suatu } \\
\text { proyek konstruksi infrastruktur di daerah pedesaan mendukung } \\
\text { keberhasilan proyek. }\end{array}$ \\
\hline 7 & Kondisi cuaca & $\begin{array}{l}\text { Produktivitas tenaga kerja suatu proyek pembangunan desa } \\
\text { dipengaruhi oleh kondisi cuaca }\end{array}$ \\
\hline 8 & Biaya & $\begin{array}{l}\text { Estimasi biaya proyek pada pembangunan desa memasukan risiko } \\
\text { ketersediaan dana dalam biaya lain-lain. }\end{array}$ \\
\hline 9 & Material & $\begin{array}{l}\text { Ketidakstabilan harga Material dapat menimbulkan } \\
\text { pembengkakan biaya yang mempengaruhi keberlangsungan } \\
\text { proyek pembangunan desa. }\end{array}$ \\
\hline 10 & Tenaga Kerja & $\begin{array}{l}\text { Kurangnya keterampilan tenaga kerja setempat menyebabkan } \\
\text { keterlambatan pembangunan di daerah pedesaan. }\end{array}$ \\
\hline 11 & Teknologi & $\begin{array}{l}\text { Keterbatasan kemampuan penggunaan perangkat lunak dalam } \\
\text { penjadwalan dapat menimbulkan risiko keterlambatan proyek } \\
\text { pembangunan desa. }\end{array}$ \\
\hline
\end{tabular}

Selanjutnya menyusun pernyataan kuesioner dengan skala Likert dan disebarkan kepada responden. Kuesioner yang terkumpul 45 responden. Dengan 1 responden yang menjawab tidak lengkap. Maka total 44 data responden yang valid. 
Tabel 4. Data Hasil Kuesioner

\begin{tabular}{|c|c|c|c|c|c|c|}
\hline No & Pernyataan & 1 & 2 & 3 & 4 & 5 \\
\hline 1 & $\begin{array}{l}\text { Adanya laporan rutin progress pekerjaan yang disetujui } \\
\text { oleh pemangku kepentingan mempengaruhi } \\
\text { keberlangsungan suatu proyek konstruksi di desa. }\end{array}$ & 0 & 0 & 9 & 20 & 16 \\
\hline 2 & $\begin{array}{l}\text { Letak lokasi desa secara geografis berdampak kepada } \\
\text { proses pengadaan sumber daya. }\end{array}$ & 0 & 2 & 6 & 24 & 13 \\
\hline 3 & $\begin{array}{l}\text { Kemampuan pelaksanaan proyek konstruksi di pedesaan } \\
\text { tergantung pada skala kontraktor. }\end{array}$ & 1 & 0 & 13 & 18 & 13 \\
\hline 4 & $\begin{array}{l}\text { Adanya perjanjian tertulis antar pihak berkepentingan } \\
\text { terkait akan melancarkan pelaksanaan proyek konstruksi } \\
\text { di pedesaan. }\end{array}$ & 0 & 0 & 9 & 17 & 19 \\
\hline 5 & $\begin{array}{l}\text { Lingkungan setempat mempengaruhi operasi } \\
\text { pelaksanaan pada daerah pedesaan. }\end{array}$ & 0 & 1 & 10 & 15 & 18 \\
\hline 6 & $\begin{array}{l}\text { Survei kondisi tanah yang dilakukan sebelum memulai } \\
\text { suatu proyek konstruksi infrastruktur di daerah pedesaan } \\
\text { mendukung keberhasilan proyek. }\end{array}$ & 1 & 0 & 6 & 15 & 23 \\
\hline 7 & $\begin{array}{l}\text { Produktivitas tenaga kerja suatu proyek pembangunan } \\
\text { desa dipengaruhi oleh kondisi cuaca. }\end{array}$ & 2 & 3 & 3 & 11 & 26 \\
\hline 8 & $\begin{array}{l}\text { Estimasi biaya proyek pada pembangunan desa } \\
\text { memasukan risiko ketersediaan dana dalam biaya lain- } \\
\text { lain. }\end{array}$ & 1 & 0 & 13 & 13 & 18 \\
\hline 9 & $\begin{array}{l}\text { Ketidakstabilan harga Material dapat menimbulkan } \\
\text { pembengkakan biaya yang mempengaruhi } \\
\text { keberlangsungan proyek pembangunan desa. }\end{array}$ & 0 & 1 & 6 & 11 & 27 \\
\hline 10 & $\begin{array}{l}\text { Kurangnya keterampilan tenaga kerja setempat } \\
\text { menyebabkan keterlambatan pembangunan di daerah } \\
\text { desa. }\end{array}$ & 0 & 0 & 6 & 23 & 16 \\
\hline 11 & $\begin{array}{l}\text { Keterbatasan kemampuan penggunaan perangkat lunak } \\
\text { dalam penjadwalan dapat menimbulkan risiko } \\
\text { keterlambatan proyek pembangunan desa. }\end{array}$ & 0 & 4 & 12 & 15 & 14 \\
\hline
\end{tabular}

\section{Uji Validitas}

Uji validitas digunakan untuk mengetahui seberapa cermat suatu item dalam mengukur apa yang ingin diukur. Item dikatakan valid jika adanya korelasi dengan skor totalnya. Teknik uji validitas yang akan digunakan dengan korelasi Pearson, yaitu dengan mengorelasikan skor item dengan skor total item tiap variabel, kemudian pengujian signifikan dilakukan denga kriteria menggunakan $r$ tabel pada tingkat signifikan 0,05 dengan uji 2 (dua) sisi. Jika nilai positif dan $r$ hitung lebih besar dari pada $r$ tabel, maka item dapat dinyatakan valid. Jika $r$ hitung lebih kecil dari pada $r$ tabel, maka item dapat dinyatakan tidak valid (Priyatno, 2019).

\section{Uji Reliabilitas}

Uji reliabilitas digunakan untuk mengetahui keajegan atau konsistensi alat ukur yang biasanya menggunakan kuesioner. Artinya, apakah alat ukur tersebut akan mendapatkan pengukuran yang tetap konsisten jika pengukuran diulang kembali. Metode yang sering digunakan dalam penelitian untuk mengukur skala rentangan (seperti skala Likert 1-5) adalah Cronbach Alpha. Uji reliablitas merupakan kelanjutan dari uji validitas, item yang masuk dalam pengujian adalah item yang valid saja dan untuk menentukan reliabel atau tidak, menggunakan batasan 0,6 . Menurut Sekaran (1992), reliabilitas kurang dari 0,6 adalah kurang baik, sedangkan 0,7 dapat diterima, dan di atas 0,8 adalah baik (Priyatno, 2019).

\section{Analisis Faktor}

Urutan asumsi yang harus terpenuhi dalam analisis faktor, antara lain (Priyatno, 2019):

1. Kaiser-Mayer-Olkin measure of sampling adequacy (KMO) digunakan untuk menguji kecukupan sampel dalam penelitian analisis faktor. Jika KMO lebih besar dari 0,5 maka diindikasikan jumlah sampel cukup memenuhi untuk digunakan dalam analisis faktor.

2. Bartlett's Test Sphericity digunakan untuk menunjukkan korelasi antara variabel secara keseluruhan. Jika signifikan kurang dari 0,05 menunjukkan adanya korelasi antara variabel secara keseluruhan. 
3. Measures of Sampling Adequacy (MSA), jika nilai MSA setiap variabel lebih besar dari 0,5 maka diindikasikan jumlah sampel cukup digunakan di dalam analisis faktor. MSA digunakan untuk menguji kecukupan variabel yang digunakan untuk analisis faktor. Nilai MSA dapat dilihat pada nilai Anti Image Correlation (pada output Anti Image Matrices) yang diagonalnya ada tanda $\alpha$.

4. Komunalitas (communalities), tabel communalities menjelaskan bahwa pada dasarnya adalah jumlah varian suatu variabel yang mula-mula bisa dijelaskan oleh faktor yang ada. Ketentuannya adalah makin besar communalities sebuah variabel, berarti makin erat hubungannya dengan faktor yang terbentuk. Nilai extraction yang kurang dari 0,5 harus dikeluarkan dan diuji ulang.

\section{ANALISIS DATA}

Sebelum melakukan analisis faktor harus melakukan uji validitas dan uji reliabilitas terlebih dahulu terhadap 11 variabel dan 44 responden. Analisis menggunakan software SPSS.

\section{Uji Validitas (Terhadap 11 Variabel)}

Uji validitas digunakan untuk mengukur valid tidaknya suatu variabel. Pengujian dilakukan dengan metode bivariate. Hasil output akan dinyatakan valid apabila nilai pearson correlation lebih besar dari pada nilai $r$ tabel. Untuk responden berjumlah 44 dengan taraf signifikansi 5\%, maka nilai $\mathrm{r}$ tabelnya adalah 0,297.

Tabel 5. Hasil Output Bivariate

\begin{tabular}{lccc}
\hline \multicolumn{1}{c}{ Variabel } & Pearson Correlation & Syarat $r$ tabel & Keterangan \\
\hline Dokumentasi & $0,714^{*}$ & 0,297 & VALID \\
\hline Lokasi & $0,635^{*}$ & 0,297 & VALID \\
\hline Skala kontraktor & $0,744^{*}$ & 0,297 & VALID \\
\hline Komunikasi & $0,631^{*}$ & 0,297 & VALID \\
\hline Lingkungan & $0,688^{*} *$ & 0,297 & VALID \\
\hline Kondisi situs & 0,296 & 0,297 & TIDAK VALID \\
\hline Kondisi cuaca & $0,552^{*}$ & 0,297 & VALID \\
\hline Biaya & $0,616^{*} *$ & 0,297 & VALID \\
\hline Material & $0,550^{*}$ & 0,297 & VALID \\
\hline Tenaga kerja & $0,420^{*}$ & 0,297 & VALID \\
\hline Teknologi & $0,779 * *$ & 0,297 & VALID \\
\hline
\end{tabular}

\section{Uji Reliabilitas (Terhadap 10 Variabel)}

Uji reliabilitas merupakan kelanjutan dari uji validitas, variabel yang masuk dalam pengujian adalah variabel yang valid saja. Uji reliabilitas dilakukan dengan menghitung koefisien cronbach alpha. Untuk menentukan reliabel atau tidak, menggunakan batasan 0,6 (Priyatno, 2018).

\section{Tabel 6. Hasil Output Reliability Statistics}

\begin{tabular}{rr}
\hline Cronbach's Alpha & Nof Items \\
\hline .835 & 10 \\
\hline
\end{tabular}

\section{Analisis Faktor}

Hasil analisis faktor hanya menampilkan hasil yang tidak memenuhi asumsi dan siklus terakhir analisis faktor. Analisis Terhadap 10 variabel (Siklus ke-1) 
Tabel 7. Hasil Output Anti-Image Matrices 1

\begin{tabular}{|c|c|c|c|c|c|c|c|c|c|c|c|}
\hline & & 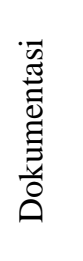 & 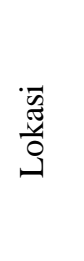 & 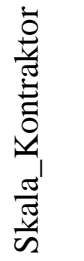 & 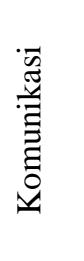 & 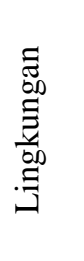 & 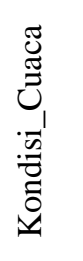 & $\stackrel{\pi}{\stackrel{\pi}{\oplus}}$ & 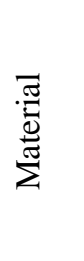 & 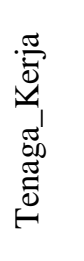 & 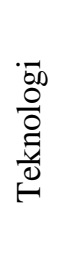 \\
\hline \multirow{10}{*}{ 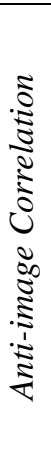 } & Dokumentasi & $.749^{\mathrm{a}}$ &,- 091 & ,179 &,- 276 & ,018 &,- 302 & ,206 &,- 409 &,- 189 &,- 239 \\
\hline & Lokasi &,- 091 & $.834^{\mathrm{a}}$ &,- 046 & ,106 &,- 228 & ,183 &,- 148 &,- 275 &,- 005 &,- 222 \\
\hline & Skala_Kontraktor & ,179 &,- 046 & $.768^{\mathrm{a}}$ &,- 257 &,- 166 &,- 333 & ,160 &,- 239 &,- 323 &,- 127 \\
\hline & Komunikasi &,- 276 & ,106 &,- 257 & $.588^{\mathrm{a}}$ &,- 253 & ,353 &,- 492 & ,217 & ,334 &,- 264 \\
\hline & Lingkungan & ,018 &,- 228 &,- 166 &,- 253 & $.811^{\mathrm{a}}$ &,- 281 & ,244 &,- 044 &,- 010 &,- 125 \\
\hline & Kondisi_Cuaca &,- 302 & ,183 &,- 333 & ,353 &,- 281 & $.623^{\mathrm{a}}$ &,- 307 &,- 080 & 219 &,- 010 \\
\hline & Biaya & 206 &,- 148 &, 160 &,- 492 & 244 &,- 307 & $.606^{\mathrm{a}}$ &,- 292 &,- 424 &,- 074 \\
\hline & Material &,- 409 &,- 275 &,- 239 & 217 &,- 044 &,- 080 &,- 292 & $.653^{\mathrm{a}}$ & ,417 & 060 \\
\hline & Tenaga_Kerja &,- 189 &,- 005 &,- 323 & ,334 &,- 010 & ,219 &,- 424 & ,417 & $.464^{\mathrm{a}}$ &,- 317 \\
\hline & Teknologi &,- 239 &,- 222 &,- 127 &,- 264 &,- 125 &,- 010 &,- 074 & ,060 &,- 317 & $.855^{\mathrm{a}}$ \\
\hline
\end{tabular}

Analisis Terhadap 9 variabel (Siklus ke-2)

Tabel 8. Hasil Output Communalities 1

\begin{tabular}{lrr}
\hline & Initial & Extraction \\
\hline Dokumentasi & 1.000 & .576 \\
\hline Lokasi & 1.000 & .466 \\
\hline Skala_Kontraktor & 1.000 & .508 \\
\hline Komunikasi & 1.000 & .741 \\
\hline Lingkungan & 1.000 & .488 \\
\hline Kondisi_Cuaca & 1.000 & .654 \\
\hline Biaya & 1.000 & .518 \\
\hline Material & 1.000 & .639 \\
\hline Teknologi & 1.000 & .711 \\
\hline
\end{tabular}

Analisis Terhadap 7 Variabel (Siklus ke-3)

Tabel 9. Hasil Output KMO dan Bartlett's Test 3

\begin{tabular}{llr}
\hline Kaiser-Meyer-Olkin Measure of Sampling Adequacy. & .730 \\
\hline \multirow{3}{*}{ Bartlett's Test of Sphericity } & Approx. Chi-Square & 94.474 \\
\cline { 2 - 3 } & $\mathrm{df}$ & 21 \\
\cline { 2 - 3 } & Sig. & .000 \\
\hline
\end{tabular}




\begin{tabular}{|c|c|c|c|c|c|c|c|c|}
\hline & & 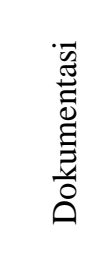 & 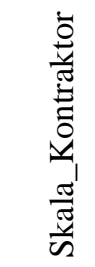 & 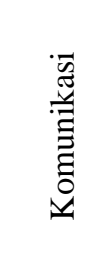 & 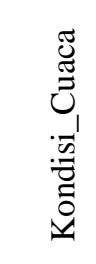 & $\stackrel{\widetilde{\pi}}{\stackrel{\vec{\sigma}}{\oplus}}$ & 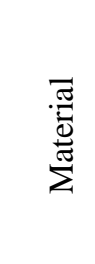 & $\begin{array}{l}\text { Do } \\
0 \\
0 \\
0 \\
0 \\
0 \\
\end{array}$ \\
\hline \multirow{7}{*}{ 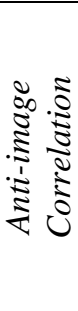 } & Dokumentasi & $.708^{\mathrm{a}}$ &, 124 &,- 231 &,- 270 & 133 &,- 423 &,- 363 \\
\hline & Skala_Kontraktor &, 124 & $.748^{\mathrm{a}}$ &,- 221 &,- 347 & ,068 &,- 171 &,- 327 \\
\hline & Komunikasi &,- 231 &,- 221 & $.718^{\mathrm{a}}$ & ,242 &,- 363 & 107 &,- 216 \\
\hline & Kondisi_Cuaca &,- 270 &,- 347 & 242 & $.701^{\mathrm{a}}$ &,- 169 &,- 184 & ,067 \\
\hline & Biaya & , 133 & ,068 &,- 363 &,- 169 & $.747^{\mathrm{a}}$ &,- 179 &,- 260 \\
\hline & Material &,- 423 &,- 171 & ,107 &,- 184 &,- 179 & $.724^{\mathrm{a}}$ & , 143 \\
\hline & Teknologi &,- 363 &,- 327 &,- 216 & ,067 &,- 260 & , 143 & $.758^{\mathrm{a}}$ \\
\hline
\end{tabular}

Tabel 11. Hasil Output Communalities 2

\begin{tabular}{lrr}
\hline & Initial & Extraction \\
\hline Dokumentasi & 1.000 & .614 \\
\hline Skala_Kontraktor & 1.000 & .511 \\
\hline Komunikasi & 1.000 & .761 \\
\hline Kondisi_Cuaca & 1.000 & .698 \\
\hline Biaya & 1.000 & .547 \\
\hline Material & 1.000 & .670 \\
\hline Teknologi & 1.000 & .703 \\
\hline
\end{tabular}

Variabel yang terdapat pada tabel output communalities 2 dan memiliki nilai extraction lebih besar dari 0,5 merupakan faktor-faktor dominan.

\section{KESIMPULAN}

Faktor-faktor manajemen proyek dominan yang mempengaruhi pelaksanaan proyek pembangunan infrastruktur di daerah pedesaan, antara lain:

- Dokumentasi

- Skala Kontraktor

- Komunikasi

- Kondisi Cuaca

- Biaya

- Material

- Teknologi

\section{SARAN}

1. Penelitian ini dapat dikembangkan dengan cara mencari besaran dampak dari tiap faktor manajemen proyek dominan terhadap pelaksanaan proyek pembangunan infrastruktur di daerah pedesaan.

2. Untuk penelitian selanjutnya, responden yang ditinjau dari perspektif konsultan, pemberi tugas, atau pengguna.

3. Untuk mengukur hasil kerja (kinerja) kontraktor proyek pembangunan infrastruktur di daerah pedesaan dapat dilakukan melalui penelitian lebih lanjut. 


\section{DAFTAR PUSTAKA}

Anondho, Basuki. (2018). Faktor Fisiologis Terukur Yang Mempengaruhi Produktivitas Tenaga Kerja Konstruksi. Jakarta: Universitas Tarumanagara.

Badan Pusat Statistik Jakarta. (2015). Banyaknya Perusahaan Konstruksi Menurut Provinsi dan Skala Perusahaan. https://www.bps.go.id/dynamictable/2015/09/19/920/jumlah-perusahaan-konstruksi-menurut-provinsi-danjenis-golongan-perusahaan-2000---2016.html (di akses 14 juni 2019).

Ervianto, I. W. (2005). Manajemen Proyek Konstruksi Edisi Revisi. Yogyakarta: Andi

Hidayat, A. (2012). Pengertian dan Penjelasan Penelitian Kuantitatif - Lengkap. https://www.statistikian.com/2012/10/penelitian-kuantitatif.html/amp (di akses 17 Juni 2019).

Kementerian Desa. (2015). Buku Data dan Informasi Penyiapan Pembangunan Daerah Tertinggal. Jakarta: Kementerian Desa, Pembangunan Daerah Tertinggal dan Transmigrasi.

Kementerian Desa. (2015). Buku Data dan Informasi Perkembangan Daerah Tertentu (Daerah Perbatasan). Jakarta: Kementerian Desa, Pembangunan Daerah Tertinggal dan Transmigrasi.

Kementerian Desa. (2015). Rencana Strategis Pengembangan Daerah Tertentu Tahun 2015-2019. Jakarta: Kementerian Desa, Pembangunan Daerah Tertinggal dan Transmigrasi.

Kermanshachi, S., Safapour, E., Anderson, S., Molenaar, K., dan Schexnayder, Cliff. (2018). "Development of The Cost Baseline for Achieving Excellence in Rural Transit Facilities". Transportation Research Board 98th Annual Conference.

Lin, X., Guo, R., dan Ling, J. (2010). "The Analysis and Recommended Solutions for Rural Roads in China". GeoShanghai 2010 International Conference, Paving Materials and Pavement Analysis, 517-522.

Priyatno, Duwi. (2019). SPSS Panduan Mudah Olah Data Bagi Mahasiswa dan Umum. Yogyakarta: Andi.

Project Management Institute. (2017). A Guide to The Project Management Body of Knowledge, (PMBOK® Guide) Sixth Edition. Jakarta: PMI Indonesia Chapter.

Ramli, M. Z., Malek, M. A., Hanipah, M. H., Lin, C. L., Sukri, M. F. M., Zawawi, M. H., Abidin, M. Z. Z., dan Fuad, N. F. S. M. (2018). "Study of Factors Influencing Construction Delays at Rural Area in Malaysia". Journal of Physics: Conference Series, Vol. 1049(1):012017.

Randolph, D. A., Abudayyeh, O., dan Menendez, M. (2003). "Role of The Engineer in Rural Municipalities". Journal of Management in Engineering, Vol. 19(3), 92-97.

Tran, D. G., Hallowell, M. R., dan Molenaar, K. R. (2015). "Construction Management Challenges and Best Practices for Rural Transit Projects". Journal of Management in Engineering, Vol. 31(5), 1-9. 
